\title{
REVIEWS
}

\section{Disruptive Domesticity in Shakespearean Drama}

Whipday, Emma. Shakespeare's Domestic Tragedies: Violence in the Early Modern Home. Cambridge: Cambridge UP, 2019. 262 pages. ISBN 9781108474030. Pbk. £29.99

\section{Zita Turi}

https://doi.org/10.30608/HJEAS/2021/27/2/14

Emma Whipday's Shakespeare's Domestic Tragedies: Violence in the Early Modern Home revisits the genre of domestic tragedy through discussions of the four great tragedies, Hamlet (1599-1601), Macbeth (c. 1606), Othello (1603-1604), and King Lear (1605-1606), together with an early comedy, The Taming of The Shrew (1590-1592). ${ }^{1}$ Whipday situates these plays in the context of popular representations of domestic conflicts and seeks to explore their spatial, psychological, and cultural implications in early modern England. The author offers an engaging and thoroughly researched discussion about the ways in which contemporaneous societal and familial constraints had an impact on individual autonomy and on the interrelations between hierarchies and gender roles within the household, revealing the domestic and social implications of hierarchical transgressions.

Whipday defines domestic tragedy as "a group of Elizabethan and Jacobean plays that portray disruption, transgression, and death in non-elite English households" (2), and she establishes correspondences among Shakespeare's sources, including Holinshed's Chronicles (1577), cheap contemporary prints of ballads, and news pamphlets. The common themes in Shakespearean domestic tragedies and in popular culture that Whipday investigates encompass "the relationship between the ideal home and its inverse; the extent to which household bonds can become criminal (or fatal); the ways in which charged domestic spaces can shape behaviour; and the impact upon the home of the surveillance, interference, and influences of 
the outside world" (2). The author regards early modern elite and popular culture in England as frequently intersecting modes of expression that reflect on certain social phenomena in the era.

The highly informative introduction establishes the context for analysis and conceptualizes the key terms and notions in the book. Whipday starts off by referring to the early modern definitions of "home," a crucial element of which was the family, and which was seen as the extension of "the householder's self" (7). This definition invites explorations of property, privacy, ownership, and their legal implications, notions which are also presented in the domestic tragedies of the time, including those of Shakespeare's, who "uses the possibilities of the genre to stage the paradoxes and vulnerabilities inherent in the early modern domestic ideology" (21). This is perhaps the greatest value of this volume: the breadth and depth of knowledge presented is impressive and the chapters offer insights into the interconnections between domestic life and its stage representations in early modern England.

The first chapter, titled "Home: Contesting Domestic Order in The Taming of the Shrew," focuses on comic shrew-narratives with reference to tropes typical in domestic tragedies, especially that of the "unhappy (and violent) husband and wife who imagine each other as dead" (22). In such cases, the stability of the household is likened to the stability of the state and to the prevalent gender hierarchy, which is "challenged and reinforced in shrew tamings" (22), and which plays an important role in all the plays the volume covers, except for King Lear. Whipday argues that although these plays, just like relevant contemporary tractates, homilies, conduct books, and marriage manuals, depict the domestic affairs of the elite; such examples of private conflict would have been familiar for Elizabethan/Jacobean audiences and thus are symptomatic of certain cultural processes in the era. These ideas are shown in comedies about domestic violence, such as The Taming of the Shrew, or the anonymous Taming of a Shrew (1594), and John Fletcher's The Woman's Prize, or The Tamer Tamed (1604-1617). These plays explore the circumstances and consequences of domestic violence and power 
struggle for which Shakespeare used a comic genre that would "withstand the risky potential of household insubordination and domestic violence" (59).

"Household: Performing Domestic Relationships in Hamlet" is a chapter examining the figure of the adulterous murderess, popular in street crime narratives and on the stages of London; the author examines how Shakespeare might have exploited this tradition when he created Gertrude's figure in Hamlet. The motives behind the murderous deeds of such female characters are usually driven by the conflict between their faithfulness to their husbands and, through their husbands, to the kingdom. Whipday argues that Shakespeare may have introduced elements of this tradition into his characterization of Gertrude's struggle between her new husband and her son, but challenges interpretations which consider her as an adulteress and a murderess. Gertrude, as Whipday continues, submits herself to "the household hierarchy when this hierarchy itself has been violated, and the fatal consequences of fully embodying the role of obedient (past and future) wife" (104). The cultural interest in the figure of the murderous wife and her ambiguous legal position, in which the wife had no legal autonomy and no right to own property, has made this theme the subject of scholarly discussions, and Whipday demonstrates its significance through the interpretations of Robert Yarington's Two Lamentable Tragedies (c. 1594), the anonymous Arden of Faversham (1592), The Witch of Edmonton written by William Rowley, Thomas Dekker, and John Ford (c. 1621), as well as through other contemporary plays.

"House: Staging Domestic Space in Othello," focusing on issues of moral and bodily female integrity in the domestic setting, explores the themes of elopement, domestic violence, and seduction in Shakespeare's comedies, poetry, and romances. The section also looks at how women and goods, with no difference in the status of the two, are regarded as "inhabitants within the home," shedding light, at the same time, on the correspondences between the female (adulterous) body and the "transgressive potential of female privacy in domestic tragedies" 
(23). Shakespeare's drama challenges concepts of female chastity in domestic settings the transgression of which, Whipday adds, does not pose a threat to familial integrity; instead, it is threatened by male jealousy and violence against women. This chapter highlights the "significance of domestic thresholds, and encapsulates the tropes used in representations of seduction and rape in early modern England" and it also touches on the idea that "the daughter or housewife within the home is figured as treasure that is stolen" (112). The topic of female privacy is explored through the analyses of the Rape of Lucrece (1594), Cymbeline (16091610), A Woman Killed with Kindness (c. 1603), and Othello.

"Neighborhood: Crossing Domestic Boundaries in Macbeth" draws on the representations of violent homes in news pamphlets and court accounts with reference to magic and associations of the perpetrator and the victim with certain spaces in the household. Whipday claims that early modern narratives about witchcraft often reflected "anxieties about sexual contagion, domestic infection, the porousness of women's bodies, subversive female agency, and the vulnerability of the self-governed and law-abiding home to disorder within the wider community" (162). She references Arnold van Gennep's study on rituals concerning thresholds and on doors to homes being boundaries between "the foreign and domestic worlds" (162) ideas also present in Macbeth - detailing modes of "boundary-crossing" (23) and the neighbors' intervention in Arden of Faversham, Two Lamentable Tragedies, The Witch of Edmonton, and Macbeth. According to Whipday, Shakespeare used patterns of contemporary pamphlets and domestic tragedy when he created the domestic world and presented the circumstances of Duncan's murder in Macbeth. She also suggests that the violation of boundaries in Macbeth's and Lady Macbeth's home ultimately leads to the violation of the kingdom.

The Afterword, "Homeless: Outside Domestic Tragedy in King Lear," examines the domestic tragedy of the homeless Lear. The central themes in King Lear are the notions of home and shelter, which represent spaces that protect against the perils of the outside world. There is 
much emphasis on the protective qualities of walls and enclosed rooms, and on the vulnerability of the household in the play. Whipday argues that domestic disintegration happens because of Lear's folly of giving up his kingdom. She also points out that Shakespeare's incorporation of elements of domestic tragedy is suggestive of the playwright's ease with which he borrowed material from cheap prints recording contemporary attitudes to domestic affairs and their associations with aspects of societal life. Thus, Shakespeare provided a "cultural conversation that stretched from the courts and scaffolds where murderers were condemned and executed" to "elite houses where spatial hierarchies were prescribed in domestic orders" (214).

Whipday concludes that Shakespeare's presentation of the discussed dramas does not imply that they would constitute a new genre; rather, she demonstrates that private and domestic affairs were subjects which would interest contemporary audiences, and thus the conventional tragedy was a fitting form for the delivery of such themes. Shakespeare used the "aesthetic distancing devices of heightened language and foreign settings to disrupt and question early modern assumptions about female agency and sexuality, social and familial bonds, and the reach of legal intervention" (220). The domestic nature of these plays, Whipday adds, is exactly what makes these stories tragic.

Shakespeare's Domestic Tragedies: Violence in the Early Modern Home is a sophisticated work that offers an original approach to a profusion of ideas and critical commentary on early modern understandings of domestic affairs and on sixteenth- and seventeenth-century intersections of elite and popular culture. It is a substantial piece of scholarship which opens a window on various aspects of early modern studies of domestic tragedy and provides insights into literary and cultural trends across genres and social classes, which will certainly be of great interest to scholars of the early modern period.

Károli Gáspár University of the Reformed Church in Hungary, Budapest 


\section{Notes}

${ }^{1}$ All the dates indicated in parentheses after the plays refer to the years in which they were written. 